\title{
NATIVE RIPARIAN TREE ESTABLISHMENT ALONG THE REGULATED DOLORES RIVER, COLORADO
}

\author{
Adam P. Coble ${ }^{1}$ and Thomas E. Kolb ${ }^{2}$
}

\begin{abstract}
Aвstract.-This study investigated influences of flow regulation of the Dolores River, Colorado, by McPhee Dam on establishment of 3 native riparian tree species (Populus angustifolia, Populus deltoides subsp. wislizenii, and Acer negundo). Tree establishment was documented with dendrochronology at 2 reference sites, the unregulated Upper Dolores and San Miguel rivers, and at multiple reaches along the Lower Dolores River for a pre-dam, canal-diverted period (1961-1984) and a post-dam period (1985-2008). Tree establishment along the Lower Dolores River relative to unregulated reference rivers was negatively affected by river regulation for $A$. negundo, but not for P. angustifolia and $P$. deltoides. For P. angustifolia, similar establishment occurred at the Upper and Lower Dolores rivers; establishment was low from 1969-1988, with greater establishment occurring prior to and following this period. For P. deltoides, pulses of tree recruitment occurred along the Lower Dolores River after river damming during 1989-1993 and 2005-2008, and overall recruitment after river damming was significantly greater than that observed for unregulated rivers. Establishment of A. negundo was low at the Lower Dolores River during the last 8 years (2001-2008) of the study period. Our results suggest that flow releases from McPhee Dam into the Lower Dolores River between 1985 and 2008 provided appropriate conditions for Populus establishment, particularly at low topographic positions within the active channel in recent years, whereas $A$. negundo may require greater flows to bolster establishment at the higher topographic positions where it often occurs.
\end{abstract}

Resumen.-Este estudio investigó las influencias de la regulación del caudal del Río Dolores, en Colorado por la Presa McPhee sobre el establecimiento de tres especies de árboles nativos riparios (Populus angustifolia, Populus deltoides subsp. wislizenii y Acer negundo). El establecimiento de árboles se documentó con dendrocronología en varios tramos a lo largo del curso inferior del Río Dolores, durante un período anterior a la construcción de la represa en el que se utilizaban canales (1961-1984) y un período posterior a la construcción de la represa (1985-2008), y en dos sitios de referencia no regulados, el curso superior del Río Dolores y el Río San Miguel. El establecimiento de árboles a lo largo del curso inferior del Río Dolores, en relación con los ríos de referencia no regulados, fue afectado de forma negativa por la regulación del río para A. negundo, pero no para $P$. angustifolia y P. deltoides. Para P. angustifolia, un establecimiento similar se produjo en los cursos inferior y superior del Río Dolores; el establecimiento fue bajo de 1969 a 1988 , con mayor establecimiento antes y después de este período. Para P. deltoides, los pulsos de reclutamiento de árboles se produjeron a lo largo del curso inferior del Río Dolores después del represamiento del río durante 1989-1993 y 2005-2008, y el reclutamiento en general después del represamiento del río fue significativamente mayor que el que se observó en los ríos no regulados. En el curso inferior del Río Dolores, el establecimiento de A. negundo fue bajo durante los último ocho años del período de estudio (2001-2008). Nuestros resultados sugieren que la liberación del caudal desde la Represa McPhee al curso inferior del Río Dolores entre 1985 y 2008, proporcionó las condiciones adecuadas para el establecimiento de Populus, particularmente en posiciones topográficas bajas dentro del canal activo en años recientes, mientras que $A$. negundo puede requerir mayores caudales para reforzar el establecimiento en las posiciones topográficas más elevadas donde suele ocurrir.

In western North America, river damming threatens many native riparian forests (e.g., Johnson et al. 1976). Due to the large ratio of reservoir storage to runoff, dams in the western United States have a greater potential to impact downstream river hydrology than dams in other U.S. regions (Graf 1999, 2006). Natural flow conditions that were once characterized by high flows during snowmelt or winter precipitation events have been altered greatly as a result of river regulation (Poff et al. 1997). Studies of regulated rivers have shown that low seedling recruitment and reduced forest cover often can be attributed to flow modification (Rood and Mahoney 1990, Merritt and Cooper 2000, DeWine and Cooper 2007, Merritt and Poff 2010).

Streamflow alteration can influence establishment of riparian trees. Germination of riparian trees in the genus Populus occurs primarily on

1School of Forest Resources and Environmental Science, Michigan Technological University, U.J. Noblet Building, 1400 Townsend Drive, Houghton, MI 49931. E-mail: apcoble@mtu.edu

${ }^{2}$ School of Forestry, Northern Arizona University, Box 15018, Flagstaff, AZ 86011 
bare, moist sediment that is supplied and created by high flows that deposit soil and scour away vegetation (Everitt 1968, Bradley and Smith 1985, Cooper et al. 1999). Attenuated flows, an outcome of river regulation, reduce geomorphic complexity and active floodplain area and subsequently diminish potential germination sites for pioneer riparian species, such as Populus fremontii and Populus deltoides (Grams and Schmidt 2002, Graf 2006). Flow conditions during the time of seed dispersal dictate the topographic elevation of the germination site (Mahoney and Rood 1998). Following germination, both the topographic elevation of seedlings and flow conditions are important factors in maintaining appropriate soil moisture to sustain growth and prevent scour of seedlings by high flows (McBride and Strahan 1984, Stromberg 1997, Mahoney and Rood 1998, Polzin and Rood 2006). Seeds deposited at low-elevation topographic positions by low flows may be susceptible to high flows or ice scour (Auble and Scott 1998). High flows scour established vegetation, deposit sediment, and contribute to the creation of nursery sites at topographic elevations suitable for seedling survival (Scott et al. 1997, Stromberg 1997, Galuszka and Kolb 2002, Cooper et al. 2003).

A few studies have shown that river regulation has no effect on tree recruitment (Beauchamp and Stromberg 2007) or that river regulation can facilitate recruitment (Johnson 1994, Shafroth et al. 2002). Establishment of Populus has been positively associated with reductions in peak flow and channel narrowing along some rivers (Johnson 1994, Shafroth et al. 2002). Reductions in peak flows can increase seedling establishment due to a decrease in flood scour and an increased number of newly exposed silt beds for germination, caused by down-cutting during channel narrowing (Johnson 1994, Shafroth et al. 2002). Higher seedling survival under dam-regulated flows also has been attributed to an increase in water supply to trees. This increased water supply is caused by an extended duration of water release from reservoirs in summer (Shafroth et al. 2002).

Much attention has been focused on establishment of Populus spp., such as prairie ( $P$. deltoides subsp. wislizenii) and Fremont ( $P$. fremontii) cottonwoods, within the Aigeiros section, but less is known about establishment of the widespread riparian species $P$. angustifolia and Acer negundo, which can reproduce through seedling recruitment and clonal processes (USDA Forest Service 1990, Rood et al. 1994). For P. angustifolia at the Animas River, Colorado, cool, wet falls were important for recruitment (Baker 1990). Recruitment of $A$. negundo along regulated rivers of the Upper Colorado River Basin has been positively associated with high peak flows (DeWine and Cooper 2007). In contrast, peak flow and recruitment of A. negundo were not associated along an unregulated stream in Arizona (Galuszka and Kolb 2002).

Here, we report results from our study of the influence of river regulation on establishment of the native riparian trees $P$. angustifolia, P. deltoides subsp. wislizenii, and A. negundo along the Dolores and San Miguel rivers in southwestern Colorado. The objectives of our study were to (1) compare effects of stream diversion via irrigation canals and flow regulation from McPhee Dam on the downstream flows of the Lower Dolores River and (2) compare tree establishment between regulated and unregulated reaches and rivers. We specifically tested the hypothesis that, for all species, establishment following river regulation along the Lower Dolores River would decrease relative to changes in establishment at unregulated comparison sites.

\section{Methods \\ Study Area}

The study area was located in southwestern Colorado on the floodplains of the Lower and Upper Dolores rivers below and above McPhee Dam, respectively, as well as the floodplains of the San Miguel River. The Dolores River begins in the San Juan Mountains in Colorado and flows northwest into the Colorado River in southeast Utah (Fig. 1). The Dolores River is regulated by McPhee Dam, constructed in 1984. McPhee Dam impounds $4.70 \times 10^{8} \mathrm{~m}^{3}$ of water for irrigation, municipal, and industrial purposes (Dolores River Dialogue 2005). The San Miguel River originates in the San Juan Mountains southeast of Telluride, Colorado, and flows northwest into the Dolores River (Fig. 1). The nearly unregulated San Miguel River contains a few diversion dams, but flow is largely controlled by snowmelt and precipitation. 


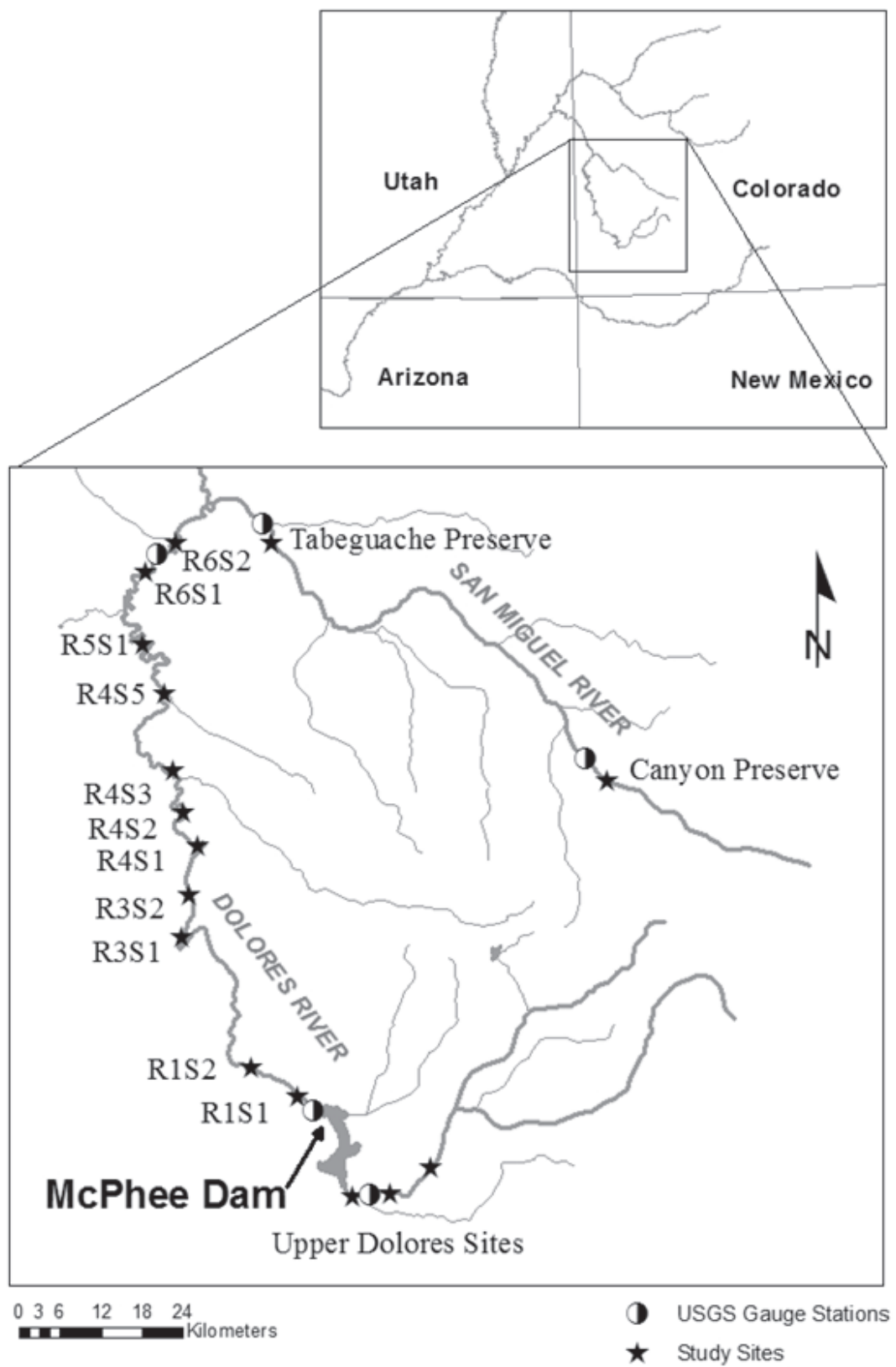

Fig. 1. Map of study sites along Upper Dolores, Lower Dolores, and San Miguel rivers. All regulated sites are designated by R (reach) and S (segment), and unregulated sites are designated by location (Upper Dolores Sites, Tabeguache and Canyon Preserves)

The study sites on the Lower Dolores River included 5 reaches $(1,3,4,5,6)$ over approximately $182 \mathrm{~km}$ of river length and an elevation difference of $539 \mathrm{~m}$ (Fig. 1). Limited access prevented sampling reach 2 . These reaches were defined by the Dolores River
Dialogue based on gradient, sinuosity, vegetation, and topography (Dolores River Dialogue 2005).

Reach 1 of the Lower Dolores River is located immediately below McPhee Dam, is $19.3 \mathrm{~km}$ long, has an approximate gradient of 
$2.37 \mathrm{~m} \cdot \mathrm{km}^{-1}$, and ranges in elevation from 2027 to 1981 m (Dolores River Dialogue 2005). Reach 3 is a narrow, confined canyon, is 14.5 $\mathrm{km}$ long, has an approximate gradient of 6.31 $\mathrm{m} \cdot \mathrm{km}^{-1}$, and ranges in elevation from 1859 to $1768 \mathrm{~m}$. Reach 4 alternates between canyons and wide valleys, is $61.2 \mathrm{~km}$ long, has a gradient of $2.29 \mathrm{~m} \cdot \mathrm{km}^{-1}$, and ranges in elevation from 1768 to $1628 \mathrm{~m}$. Reach 5 flows through narrow and sinuous Slickrock Canyon, is 67.6 $\mathrm{km}$ long, has a gradient of $2.08 \mathrm{~m} \cdot \mathrm{km}^{-1}$, and ranges in elevation from 1628 to $1524 \mathrm{~m}$. Reach 6 is located at Saucer Basin just above the confluence of the Dolores and San Miguel rivers where Slickrock Canyon opens into the wide Paradox Valley, is $19.3 \mathrm{~km}$ long, has a gradient of $1.89 \mathrm{~m} \cdot \mathrm{km}^{-1}$, and ranges in elevation from 1524 to $1487 \mathrm{~m}$.

We pooled data for $P$. angustifolia establishment over reaches 1 and 3 , and for $A$. negundo establishment over reaches 1 and 3 and over reaches 4,5 , and 6 to obtain a more robust sample size that more closely matched the sample size for our unregulated comparison rivers, the Upper Dolores and San Miguel rivers. For example, only 2 and $4 \mathrm{~A}$. negundo trees established at reaches 5 and 6 , respectively; 24 established at reach 4; and 12 established at the San Miguel River. In contrast, data at reaches 4 and 6 were not pooled for $P$. deltoides because the number of trees that established at each reach (70 trees at reach 4 and 57 trees at reach 6) closely matched the number of trees at the San Miguel River (75 trees). The unregulated comparison sites and their paired sites along the regulated Lower Dolores River are described below.

Less is known about the sites located along the San Miguel and Upper Dolores rivers. The range in elevation was 2182 to $2110 \mathrm{~m}$ for the Upper Dolores River, 1570 to $1550 \mathrm{~m}$ for the Tabeguache Preserve at the San Miguel, and 2160 to $2150 \mathrm{~m}$ at the Canyon Preserve at the San Miguel. We selected these unregulated comparison sites based on their similarity to specific reaches of the Lower Dolores River in elevational and geomorphic characteristics. The Dolores River sites above McPhee Dam provided the best comparison sites for reaches 1 and 3 of the Lower Dolores River due to accessibility, elevation, and similarities in floodplain geomorphology. The Canyon Preserve of the San Miguel River was a potential comparison site for reaches 1 and 3 , but this site had a narrower floodplain, steeper gradient, and did not match the elevation of reaches 1 and 3 as closely as the Upper Dolores River sites. Thus, the Canyon Preserve was not used as a comparison site, but we provide results from this site, as they may be useful for future studies of $P$. angustifolia establishment. The elevation was lower at reaches 1 and $3(2027-1768 \mathrm{~m})$ than at the Upper Dolores sites $(2182-2110 \mathrm{~m})$, but the San Miguel River was not accessible at elevations similar to those of reaches 1 and 3. The Tabeguache Preserve of the San Miguel River was the comparison site for reaches 4,5 , and 6 of the Lower Dolores River because these sites had similar elevations (1768-1487 $\mathrm{m}$ at reaches 4,5 , and 6 and $1570-1550 \mathrm{~m}$ at the Tabeguache Preserve) and were unconstrained by bedrock, with the exception of a few segments in reach 5 .

The study site along the Upper Dolores River above McPhee Dam included 3 segments: the western bank of the river near mile marker 17 along Hwy. 145, the eastern bank of the river across from the Dolores Public Library, and the eastern bank of the river across from Joe Rowell Park in the town of Dolores. The 2 study sites on the San Miguel River were located at the Tabeguache and Lower Canyon Preserves, managed and owned by The Nature Conservancy. The Tabeguache Preserve is located along Hwy. 141 between mile markers 67 and 74, just above the confluence of the San Miguel River and Tabeguache Creek. The Canyon Preserve is located along Hwy. 145, $6.4 \mathrm{~km}$ north of Placerville, CO.

\section{Delineation of Segments}

Field sampling was conducted in the spring and summer of 2009 and 2010. At the Lower Dolores River, each reach was divided into 2 , 3 , or 5 equal-length segments, depending on reach length (Fig. 1). Segment 4 of reach 4 was not sampled due to difficult access. Prior to selecting sample locations within a segment, we scouted the entire segment. Locations were selected that contained a broad range of tree size classes. If the segment did not contain stands with a broad range of size classes, we started at the beginning of the segment and traveled downstream, sampling trees within the entire segment. At the San Miguel River, the $11.2-\mathrm{km}$ stretch of river at the Tabeguache Preserve was divided into 2 equal-length 
segments. The 3.2-km stretch of river at the Canyon Preserve was considered one segment. At the Upper Dolores River above McPhee Dam, 3 segments of river were selected on public lands in or upstream of the town of Dolores.

\section{Tree Sampling and Measurement}

Our objective for tree sampling was to determine the approximate year of establishment for the population of trees at each reach. Three trees per size class were cored using an increment borer at each reach segment. Tree size classes were defined in $5.0-\mathrm{cm}$ increments of diameter at breast height (dbh), and a tree size class was also designated for small trees that were shorter than breast height (i.e., $<1.4 \mathrm{~m}$ ). Trees that originated as seedlings or root sprouts were not separated because we were interested in all forms of regeneration (Baker 1990, Galuszka and Kolb 2002). We did not collect data on seed production in each reach due to logistical constraints and because seed production during the time of sampling may not reflect seed production in historical establishment periods. However, an attempt was made to identify seed production timing with gaming cameras, but the resolution was not fine enough to observe seed dispersal events.

We excavated the soil around each tree, at times digging to a depth of approximately $1 \mathrm{~m}$, to expose and identify the root collar and to provide room for the increment borer. We cored trees $6-10 \mathrm{~cm}$ above the root collar using an increment borer. For the larger trees $(10-100 \mathrm{~cm} \mathrm{dbh})$, we extracted 2 increment cores spaced $90^{\circ}$ apart per tree; for saplings $(0-9.9 \mathrm{~cm} \mathrm{dbh})$, we extracted only one core per tree. For trees with a diameter at coring height $<3 \mathrm{~cm}$, we either collected a stem cross-section above the root collar at locations where small trees were abundant or estimated ages by counting bud scale scars on the aboveground section of the stem where small trees were not abundant.

We prepared the cores for analysis in the laboratory by gluing them into wood mounts and sanding them using a series of sandpaper grades (Stokes and Smiley 1968). For cores that included the pith, tree age was determined by using a dissecting scope to count annual rings. Tree age for problematic cores (e.g., cores containing false rings or rings that were difficult to see near the pith) was verified by 3 experienced dendrochronologists. At all sites, cores from mature trees that established prior to construction of McPhee Dam (1984) were cross-dated, checked, and corrected for missing or false rings using the software program COFECHA (Grissino-Mayer 2001). Younger trees that established after McPhee Dam (1984) were visually cross-dated by matching patterns of wide and narrow rings with chronologies developed for mature trees.

For cores that did not contain the pith, 2 methods of estimating age were compared for $P$. deltoides and $P$. angustifolia at 2 sites that contained a high sample size of trees, reach $4 /$ segment 5 and reach $1 /$ segment 1 . The first method involved selecting sampled trees that contained 2 cores, one with the pith and one without the pith. For the core without the pith, the template method was used to estimate tree age (Applequist 1958). The second method predicted age of the same trees used for the first method based on the regression relationship between tree age and diameter at coring height. Thus, for these trees, we obtained ages by both direct observation and prediction via 2 methods. Correlations between predicted and observed ages were compared between methods at each site.

The template method was superior to the age-diameter method for predicting tree age. At reach 1/segment 1, the relationship between predicted and observed ages was significant for both the template and age-diameter methods $(P<0.0001)$; however, the correlation between predicted and observed ages was lower for the age-diameter method $(r=0.94)$ than the template method $(r=0.96)$. Similarly, at reach $4 /$ segment 5 , the correlation between predicted and observed ages was lower for the age-diameter method $(r=0.83)$ than the template method $(r=0.95)$. Consequently, the template method was used to predict ages of trees with both increment cores not containing the pith.

\section{Hydrologic and Climatic Variables}

Dolores River flow data were obtained for the Dolores (09166500) and Bedrock (09169500) Gauge Stations from the U.S. Geological Survey, and for the Dolores River Below McPhee Reservoir (DOLBMCCO) Gauge Station from the Colorado Division of Water Resources. These data included daily flow records from 
TABLE 1. Chi-square tests of expected percent increase in tree establishment between pre-dam to post-dam periods based on the change at the reference reaches, and observed percent increase in establishment at regulated reaches for 3 tree species.

\begin{tabular}{lllrrrrr}
\hline Species & $\begin{array}{c}\text { Reference } \\
\text { river }\end{array}$ & $\begin{array}{c}\text { Regulated } \\
\text { reach }\end{array}$ & $\begin{array}{c}\text { Expected } \\
\text { increase } \\
(\%)\end{array}$ & $\begin{array}{c}\text { Observed } \\
\text { increase } \\
(\%)\end{array}$ & df & $\chi^{2}$ & $P$ \\
\hline Populus angustifolia & Upper Dolores & Reaches 1 and 3 & 267 & 278 & 0 & - & - \\
Populus deltoides & San Miguel & Reach 4 & 60 & 89 & 1 & 2172.3 & $<0.001$ \\
Acer negundo & San Miguel & Reach 6 & 60 & 418 & & 59.56 & $<0.001$ \\
& Upper Dolores & Reaches 1 and 3 & 82 & 54 & 1 & 500 \\
\hline
\end{tabular}

October 1961 through October 2008 at the Dolores Gauge and from October 1971 through October 2008 at the Bedrock Gauge. At Bedrock, missing data from 1961 to 1971 were predicted by linear regression of seasonal flow variables between the Bedrock and Cisco Gauge Stations for years 1972 to 1984 . The Cisco Gauge Station (09180000) was located downstream from the Bedrock Gauge and was used to predict seasonal flow variables at Bedrock. The coefficient of determination $\left(r^{2}\right)$ of seasonal flow variables between the Bedrock and Cisco Gauge Stations ranged from 0.84 to 0.95 , and all $P$ values were $<0.001$.

Flow data for the San Miguel River were obtained for the Uravan (09177000) and Placerville (09172500) Gauge Stations from the U.S. Geological Survey. These data include daily flow records from October 1974 through October 2008 at the Uravan Gauge and from October 1961 through October 2008 at the Placerville Gauge. At Uravan, missing data from 1961 to 1973 were predicted via linear regression of seasonal flows between the Uravan and Placerville Gauge Stations (19742008). The coefficient of determination $\left(r^{2}\right)$ of seasonal flows between the 2 gauge stations ranged from 0.73 to 0.92 , and all $P$ values were $<0.0001$.

\section{Data Analysis}

Statistical analyses were conducted using $\mathrm{R}$ statistical software (R Development Core Team 2011). Relationships among mean seasonal (spring and summer) and instantaneous peak flows of the 3 rivers were examined using regression. Rather than reporting specific years of tree establishment, we grouped tree ages into 4-year establishment periods due to the uncertainty introduced by the template technique for predicting tree age. Shafroth et al. (2002) used a similar approach to identifying years of cottonwood establishment by grouping ages determined by coring and crosssections into 5-year intervals. Our use of a 4-year interval allowed us to partition the preand post-dam periods into the same number of intervals (6). Chi-square tests were conducted on expected and observed values of percent increase in establishment from predam to post-dam periods for each species. The expected values of establishment were calculated by dividing the total number of trees established after damming by the total number of trees established before damming at reference (unregulated) rivers. The observed values were calculated in the same manner for reaches along the regulated Lower Dolores River. Specific reaches along the Lower Dolores River and their paired reference reaches used in the chi-square tests are listed in Table 1.

\section{Results}

Instantaneous peak and mean spring flows (1 Apr-30 Jun) were similar at the Upper Dolores and Lower Dolores rivers during the pre-dam period (1961-1984), except during years of high flow, when flow was greater at the Lower Dolores River (Fig. 2a, 2b). During the post-dam period (1985-2008), peak and spring flows were consistently lower at the Lower Dolores River than the Upper Dolores River, particularly during years of low flow (Fig. 2a, 2b). During both pre- and post-dam periods, peak and spring flows of the San Miguel River were consistently lower than those of the Upper Dolores River, but the temporal pattern was similar (peak flow: $r^{2}=$ 0.74, $P<0.001$; spring flow: $r^{2}=0.86, P<$ 0.001 ; Fig. $2 \mathrm{a}, 2 \mathrm{~b}$ ). During the pre- and postdam periods, mean summer flow (1 Jul-30 Sep) at the Lower Dolores River was consistently lower than flow at the Upper Dolores 


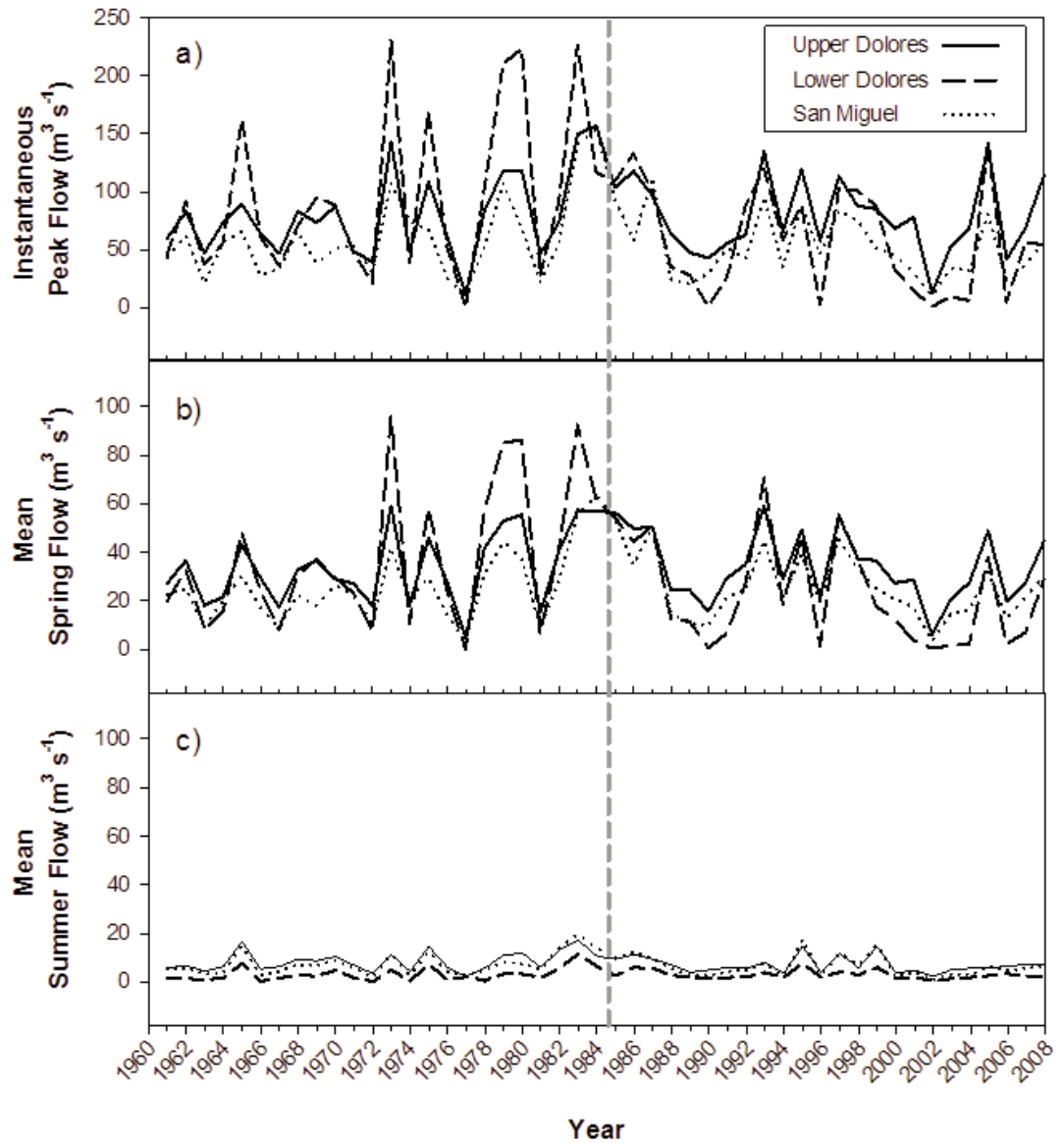

Fig. 2. Instantaneous peak (a), mean spring (1 April-30 June; b), and mean summer (1 July-30 September; c) flow from 1961 to 2008 at the unregulated Upper Dolores, regulated Lower Dolores, and unregulated San Miguel rivers. Construction of McPhee Dam was completed in the fall of 1984 as indicated by the vertical dashed line in all figure panels.

River, but the temporal pattern was similar $\left(r^{2}\right.$ $=0.79, P<0.001$; Fig. $2 \mathrm{c})$. Mean summer flow at the San Miguel River was similar to mean summer flow at the Upper Dolores River $\left(r^{2}\right.$ $=0.90, P<0.001$; Fig. $2 \mathrm{c}$ ).

At reaches 1 and 3 of the Lower Dolores River, we observed a $278 \%$ increase in $P$. angustifolia establishment between the predam and post-dam periods that was similar to the increase $(267 \%)$ that occurred at the Upper Dolores River reference site (Table 1). At reach 4 of the Lower Dolores River, $P$. angustifolia establishment was not detected prior to 1985 (Fig. 3c). This delay prevented a calculation of percent increase in establishment and subsequent statistical analysis of $P$. angustifolia establishment due to insufficient degrees of freedom. We classified tree establishment as low, moderate, or high when, respectively, $<5$, $5-15$, or $>15$ live trees that we sampled were dated as having established in a reach within a 4-year interval. We observed an extended period of low establishment years for $P$. angustifolia from 1969 to 1988 and moderate establishment prior to and following this period at the Upper Dolores River (Fig. 3a). Establishment of $P$. angustifolia was low at reaches 1 and 3 of the Lower Dolores River from 1969 to 1996 and moderate prior to and following this time period (Fig. 3b). The 2 trees of $P$. angustifolia that established during the 19851988 period at reach 4 asexually propagated via root suckers during the 2001-2004 and 2005-2008 intervals (Fig. 3c). At the unregulated San Miguel River (Tabeguache Preserve), moderate establishment of $P$. angustifolia 


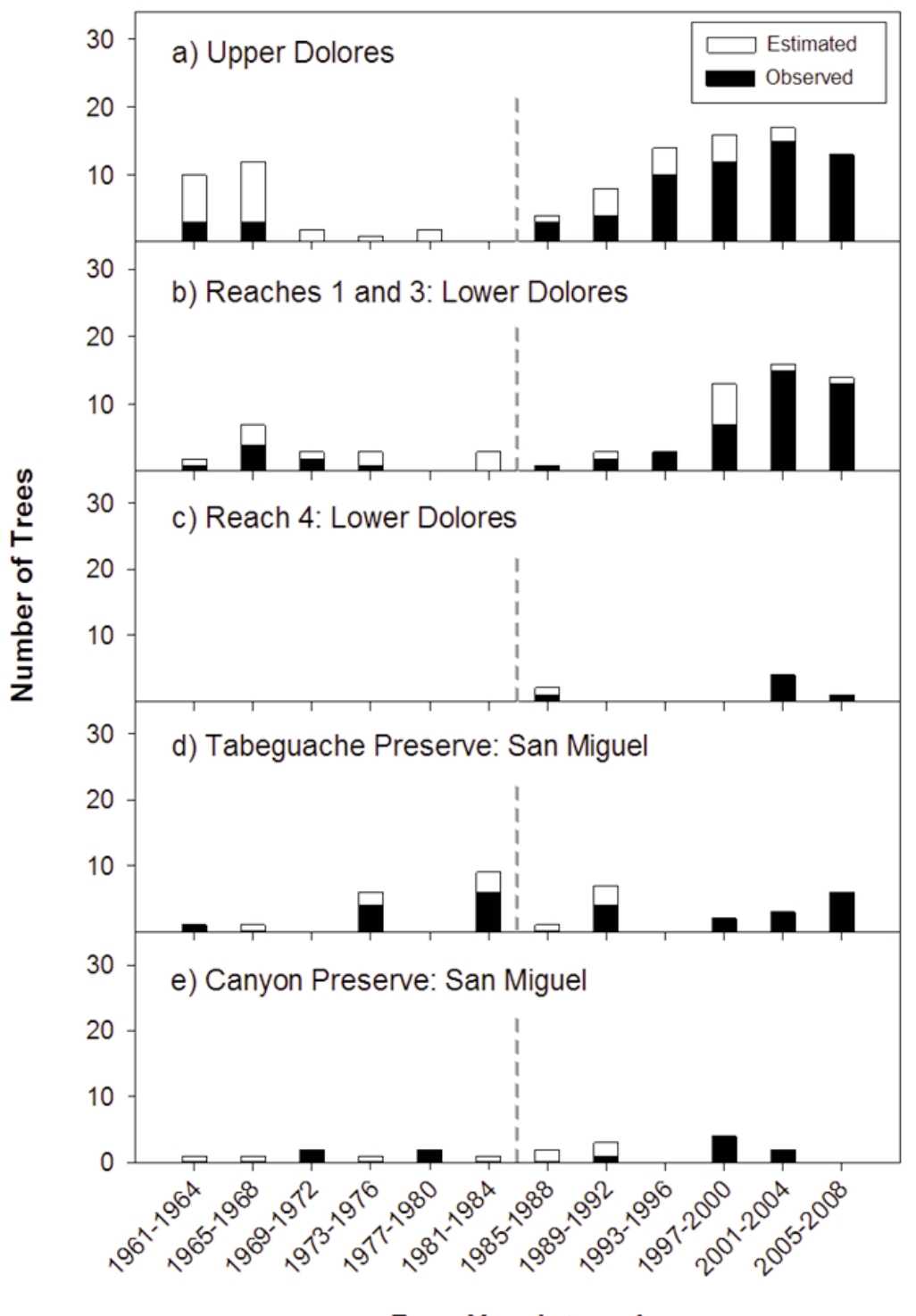

Four-Year Interval

Fig. 3. Number of Populus angustifolia trees that established in sample reaches in 4-year periods at (a) the Upper Dolores River, (b) reaches 1 and 3, Lower Dolores River, (c) reach 4, Lower Dolores River, (d) Tabeguache Preserve, San Miguel River, and (e) Canyon Preserve, San Miguel River. The number of trees is shown separately for tree ages observed directly by counting rings to pith and for tree ages estimated by the template method when pith was missing. Construction of McPhee Dam was completed in fall 1984 as indicated by the vertical dashed line in all figure panels.

occurred during the 1973-1976, 1981-1984, 1989-1992, and 2005-2008 periods (Fig. 3d). At the Canyon Preserve, establishment of $P$. angustifolia was consistent but low (Fig. 3e).

We observed a significant increase in P. deltoides establishment at the Lower Dolores River following river damming by McPhee Dam (Table 1). Moderate establishment occurred from 1961 to 2008 at reach 4 of the Lower Dolores River, with one exception (Fig. 4a). The exception is low establishment from 1989 to 1996 (Fig. 4a). At reach 6 of the Lower Dolores River, low establishment was common from 1961 to 2008 (Fig. 4b). However, moderate and high establishment occurred during the 1989-1992 and 1993-1996 periods, 


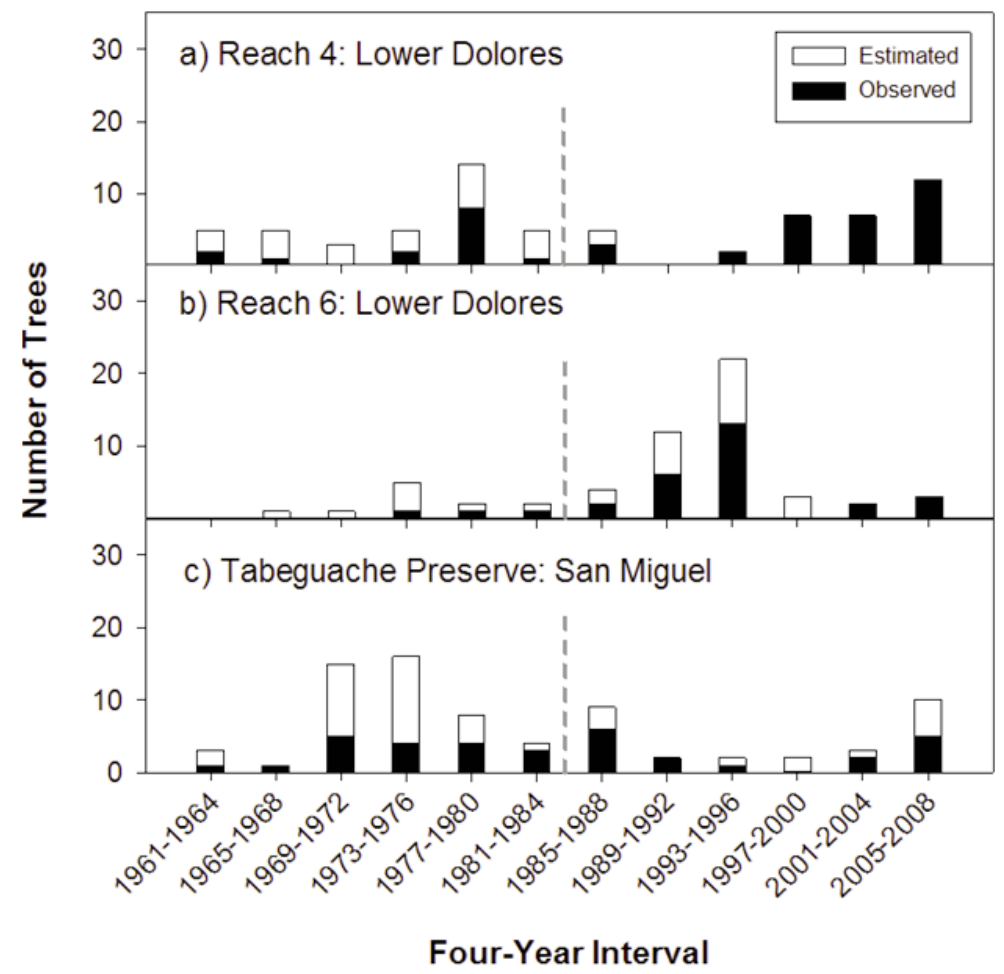

Fig. 4. Number of Populus deltoides subsp. wislizenii trees that established in sample reaches in 4-year periods at (a) reach 4, Lower Dolores River, (b) reach 6, Lower Dolores River, and (d) Tabeguache Preserve, San Miguel River. The number of trees is shown separately for tree ages observed directly by counting rings to pith and for tree ages estimated by the template method when pith was missing. Construction of McPhee Dam was completed in fall 1984 as indicated by the vertical dashed line in all figure panels.

respectively (Fig. 4b). At the unregulated San Miguel River, establishment was moderate to high from 1969 to 1988 and low from 1989 to 2004 (Fig. 4c).

For A. negundo, the percent increase in establishment between pre- and post-dam periods was significantly lower at the Lower Dolores River compared to the Upper Dolores and San Miguel rivers (Table 1), despite frequently low establishment at these unregulated reference sites (Fig. 5a, 5d). This finding occurred for 2 reasons. First, we observed a decline in establishment at both the Upper Dolores River and reaches 1 and 3 during the post-dam period, but the decline was greater at reaches 1 and 3. Second, A. negundo establishment increased at the San Miguel River between pre- and post-dam periods, whereas establishment was similar for pre- and postdam periods at the Lower Dolores River. At reaches 4,5 , and 6 of the Lower Dolores River, establishment of A. negundo did not occur during the 2 most recent periods (20012004 and 2005-2008) (Fig. 5c). At all sites along the Dolores River, we observed no establishment of A. negundo from 2005 to 2008 (Fig. 5).

\section{Discussion}

Our results do not support our hypothesis that damming and flow regulation of the Lower Dolores River would reduce $P$. angustifolia establishment. Despite noticeable reduction in peak flow, we did not observe a decrease in $P$. angustifolia establishment below McPhee Dam during the post-dam period (1985-2008) relative to the Upper Dolores and San Miguel River reference sites. Establishment of $P$. angustifolia over the 48-year period of analysis was similar between the unregulated Upper Dolores River reference site and the regulated Lower Dolores River. Distinct periods of low and high establishment at the 


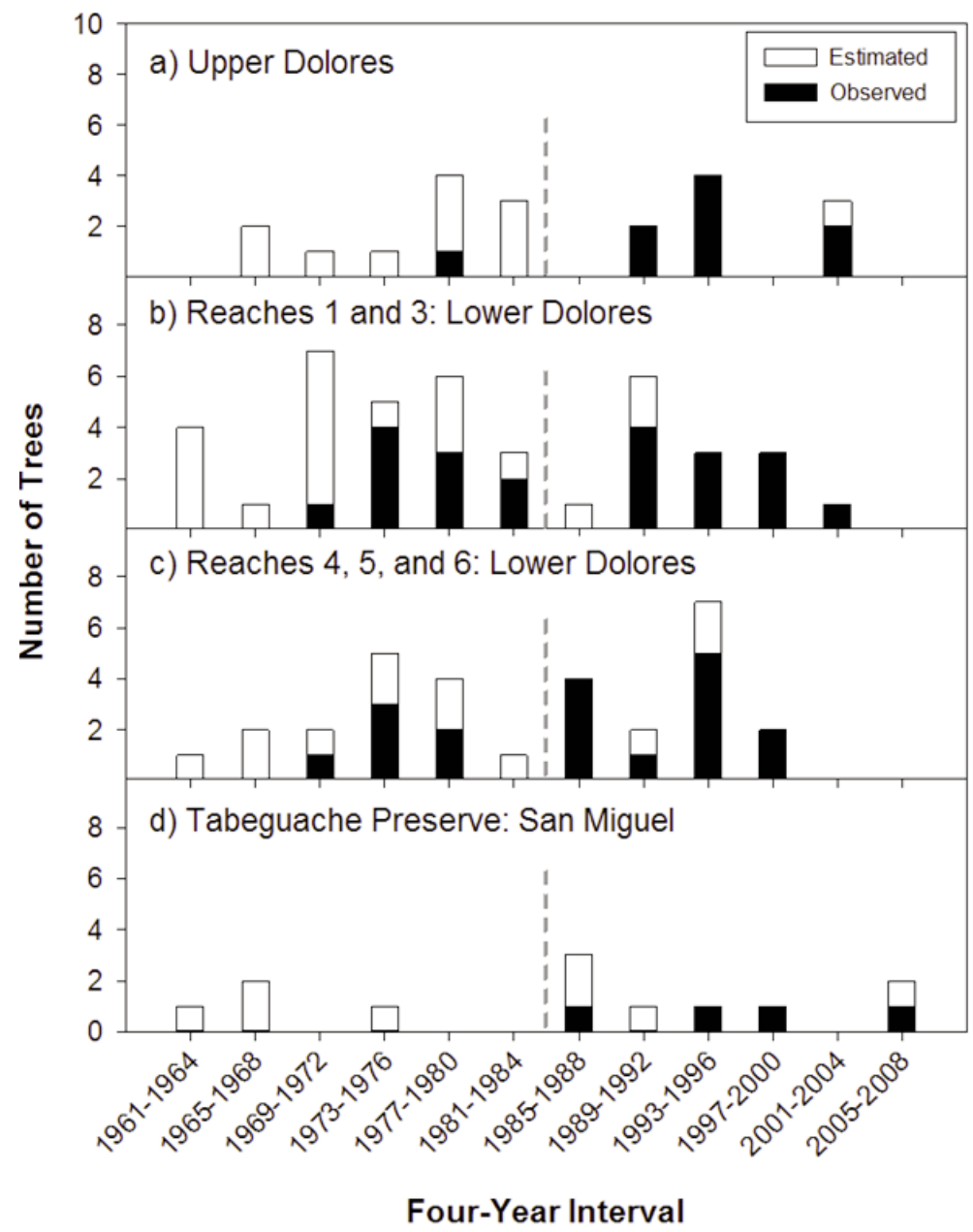

Fig. 5. Number of Acer negundo trees that established in sample reaches in 4-year periods at (a) the Upper Dolores River, (b) reaches 1 and 3, Lower Dolores River, (c) reaches 4, 5, and 6, Lower Dolores River, and (d) Tabeguache Preserve, San Miguel River. The number of trees is shown separately for tree ages observed directly by counting rings to pith and ages estimated by the template method when pith was missing. Construction of McPhee Dam was completed in fall 1984 as indicated by the vertical dashed line in all figure panels.

Upper Dolores generally coincided with periods of low and high establishment at the Lower Dolores River. However, the period of low establishment lasted into the mid-1990s at the Lower Dolores River, whereas establishment was moderate at the Upper Dolores River during this time. River damming may have moderately reduced $P$. angustifolia establishment from 1989 to 1996 along the Lower Dolores, but not in other years. Overall, $P$. angustifolia establishment was generally abundant along the Lower Dolores River during the post-dam period.

At the nearby Animas River, Colorado, Baker (1990) aged P. angustifolia seedlings and mature trees. Consistent with Baker's analysis, we observed moderate establishment around 1968 at the Upper and Lower Dolores rivers and around 1975 at the San Miguel River. The year 1975 was not an apparent stand-origin year at the Lower Dolores River as reported by Baker (1990) for the Animas River. Moreover, we documented low establishment of $P$. angustifolia from 1975 to 1985 along the Upper and Lower Dolores rivers, whereas high establishment ( $>15$ seedlings per year for 9 of 11 years) was reported along the Animas River during that period (Baker 1990). We also observed inconsistencies in years of $P$. angustifolia 
establishment between the Dolores and San Miguel rivers. These inconsistencies suggest temporal asynchrony in establishment of $P$. angustifolia over different rivers in southwestern Colorado.

Our results for $P$. deltoides also do not support our hypothesis that damming and flow regulation of the Lower Dolores River would reduce establishment. Specifically, we found greater establishment of $P$. deltoides along the Lower Dolores River after damming relative to references sites. Interestingly, most $P$. deltoides trees at reach 6 of the Lower Dolores River established after damming from 1989 to 1996. Increased establishment of Populus has been reported after river damming for the Bill Williams, North Platte, South Platte, and Platte rivers (Johnson 1994, Shafroth et al. 2002). Along these regulated rivers in the western United States, reductions in flow magnitude after damming allowed establishment of Populus in former active channels (Johnson 1994, Shafroth et al. 2002). Shafroth et al. (2002) suggested that seedling survival rates were greater during the post-dam period due to increased summer average flows and lack of high scouring flows during the late-summer monsoon season. We speculate that the pulse of $P$. deltoides establishment following river damming at the Lower Dolores River in our study was due, in part, to channel narrowing and subsequent seedling colonization of exposed sediment.

Noticeable spikes in $P$. deltoides establishment occurred at reaches 4 and 6 of the Lower Dolores River during the following 4-year intervals: 1977-1980, 1993-1996, and 2005-2008. These periods coincide with years of high instantaneous peak flow. For example, peak flows in 1979 and 1980 were 210 and $223 \mathrm{~m}^{3} \cdot \mathrm{s}^{-1}$, respectively. The 1979 and 1980 floods were the third and fourth highest peak flows observed during the entire study period (19612008). Also, high peak flows were observed in 1993 and 2005. The 1993 and 2005 floods were the third highest and highest peak flows observed during the post-dam period (19852008). However, we did not observe spikes in $P$. deltoides establishment during the 2 highest peak flow years, 1973 and 1983. Thus, high flows and subsequent exposure of moist sediment for a few specific years, in combination with channel narrowing and colonization of exposed sediment, appeared to facilitate $P$. deltoides establishment in some but not all years.
Our finding of a positive impact of river damming and regulation on establishment of $P$. deltoides at the Lower Dolores River differs from a similar study of the same species at the regulated Green River. In contrast to our study on the Lower Dolores River, establishment was uncommon for $P$. deltoides along the regulated Green River following construction of Flaming Gorge Dam (Merritt and Cooper 2000, Cooper et al. 2003). According to Merritt and Poff (2010), flow modification was greater along the Lower Dolores River (index of flow modification $[\mathrm{IFM}]=0.21)$ than along the Lower Green River (IFM = 0.10), suggesting that McPhee Dam (Dolores River) has had a greater impact on streamflow compared to the Flaming Gorge Dam (Green River). We speculate that differences in the timing of dam construction or geomorphological characteristics between the 2 rivers may have resulted in different outcomes of Populus establishment.

At our study sites along the Lower Dolores River, most young Populus deltoides trees $(82 \%$ of trees $<10$ years old) established within active or ephemeral channels, a finding consistent with an earlier study (Dolores River Dialogue 2005). Using HEC-RAS river modeling software, preliminary analysis revealed that instantaneous streamflow of $56 \mathrm{~m}^{3} \cdot \mathrm{s}^{-1}$ would inundate the active floodplain of the Lower Dolores River (Dolores River Dialogue 2005), which includes the active and ephemeral channels in our study. This result suggests that $P$. deltoides seedlings growing close to the channel are susceptible to scouring during high floods (e.g., Cooper et al. 1999). Our results, however, do not fully support this suggestion because some $P$. deltoides seedlings in active and ephemeral channels along the Lower Dolores River survived instantaneous peak flows of $143 \mathrm{~m}^{3} \cdot \mathrm{s}^{-1}$ in 2005. Our results provide evidence that young Populus trees can persist through inundation and high flows within the active channel.

In contrast to the Populus species in our study, we found support for our hypothesis that damming and flow regulation of the Lower Dolores River would reduce A. negundo establishment. Establishment of A. negundo did not occur from 2005 to 2008 at reaches 1 and 3 and from 2001 to 2008 at reaches 4, 5, and 6 . DeWine and Cooper (2007) suggested that large floods in narrow canyons facilitate $A$. negundo establishment by creating moist soil conditions conducive to seedling germination. 
We speculate that reductions in peak flow during the post-dam period prevented establishment of $A$. negundo at our study sites, particularly during the last 8 years of the study period. Most young A. negundo trees (89\% of trees $<10$ years old) in our study established at the first bench position. Mature A. negundo trees were growing at higher elevation above the stream channel on benches (1.2 to $2.4 \mathrm{~m}$ ) than were Populus spp. (0.8-1.2 $\mathrm{m}$ in wide, alluvial valleys and $1.7 \mathrm{~m}$ in narrow canyon reaches). Our finding that $A$. negundo established at higher topographic positions than $P$. deltoides is consistent with the Johnson et al. (1976) report that A. negundo inhabits higher terraces near the edge of the floodplain along the regulated Missouri River, North Dakota. Thus, high flows appear to be more important for establishment of A. negundo than Populus spp. along the Lower Dolores River.

\section{Conclusions and Management IMPLICATIONS}

Our dendrochronological approach provided information about important years of tree establishment for Populus angustifolia, Populus deltoides, and Acer negundo during the pre-dam, canal-diverted period (1961-1984) and post-dam period (1985-2008) along the Lower Dolores River and unregulated reference sites along the Upper Dolores and San Miguel rivers. River regulation by McPhee Dam did not reduce Populus establishment relative to the unregulated reference rivers (Upper Dolores and San Miguel rivers). In contrast to our findings for Populus, Acer negundo establishment along the Lower Dolores River was negatively affected by river damming relative to the references sites. Seasonal variation in streamflow, such as high flow during May and June followed by receding flows in July through September, should continue to be maintained in the Lower Dolores River, and extreme departure from natural seasonal variation in streamflow should be avoided to allow establishment of native trees. This avoidance is particularly important for Acer negundo, which tends to establish at higher topographic positions.

\section{ACKNOWLEDGMENTS}

This research was made possible by the financial support of the Dolores River Dialogue, the Office of the Vice-President for
Research, and the School of Forestry at Northern Arizona University. We thank Kristen M. Waring, Margaret M. Moore, Robert Nowak, and several anonymous reviewers for their helpful comments on earlier versions of this manuscript. We thank Rob Anderson, Jeff Kane, John Godbey, and Elizabeth Camarata for their assistance in the field research work. We thank David Graf for assistance with obtaining diversion data and data analysis. We thank Cara MacMillan and the Dolores Public Lands Office for providing resources to conduct this research. We thank Larry and Jim Suckla, Vicki Phelps, Mark Youngquist, and the Nature Conservancy for allowing us to conduct research on their properties along the Dolores and San Miguel rivers. We thank Don Normandin and the Ecological Restoration Institute for their assistance in the woodshop.

\section{Literature Cited}

APPLEQuist, M.B. 1958. A simple pith locator for use with off-center increment cores. Journal of Forestry 56 : 141.

Auble, G.T., AND M.L. SCOTT. 1998. Fluvial disturbance patches and cottonwood recruitment along the Upper Missouri River, Montana. Wetlands 18:546-556.

BAKER, W.L. 1990. Climatic and hydrologic effects on the regeneration of Populus angustifolia James along the Animas River, Colorado. Journal of Biogeography $17: 59-73$

Beauchamp, V.B., and J.C. Stromberg. 2007. Flow regulation of the Verde River, Arizona encourages Tamarix recruitment but has minimal effect on Populus and Salix stand density. Wetlands 27:381-389.

Bradley, C.E., and D.G. Smith. 1985. Plains cottonwood recruitment and survival on a prairie meandering river floodplain, Milk River, southern Alberta and northern Montana. Canadian Journal of Botany 64: 1433-1442.

Cooper, D.J., D.C. Andersen, and R.A. Chimner. 2003. Multiple pathways for woody plant establishment on floodplains at local to regional scales. Journal of Ecology 91:182-196.

Cooper, D.J., D.M. Merritt, D.C. Andersen, and R.A. Chimner. 1999. Factors controlling the establishment of Fremont cottonwood seedlings on the Upper Green River, USA. Regulated Rivers: Research \& Management 15:419-440.

DEWINE, J.M., AND D.J. COOPER. 2007. Effects of river regulation on riparian box elder (Acer negundo) forests in canyons of the Upper Colorado River Basin, USA. Wetlands 27:278-289.

Dolores River Dialogue. 2005. Core science report for the Dolores River Dialogue. Fort Lewis College, Durango, CO; [cited 8 October 2012]. 133 pp. Available from: http://ocs.fortlewis.edu/drd/pdf/coreScie nceReport.pdf

EveritT, B.L. 1968. Use of the cottonwood in an investigation of the recent history of a flood plain. American Journal of Science 266:417-439. 
GaluszKa, D.M., AnD T.E. KolB. 2002. Tree growth and regeneration response to climate and stream flow in a species-rich southwestern riparian forest. Western North American Naturalist 62:266-279.

Graf, W.L. 1999. Dam nation: a geographic census of American dams and their large-scale hydrologic impacts. Water Resources Research 35:1305-1311.

2006. Downstream hydrologic and geomorphic effects of large dams on American rivers. Geomorphology 79:336-360.

Grams, P.E., AND J.C. SCHMIDT. 2002. Streamflow regulation and multi-level flood plain formation: channel narrowing on the aggrading Green River in the eastern Uinta Mountains, Colorado and Utah. Geomorphology 44:337-360.

GrissinO-MaYer, H.D. 2001. Evaluating cross-dating accuracy: a manual and tutorial for the computer program COFECHA. Tree Ring Research 57:205-221.

Johnson, W.C. 1994. Woodland expansion in the Platte River, Nebraska: patterns and causes. Ecological Monographs 64:45-84.

Johnson, W.C., R.L. Burgess, and W.R. Keammerer. 1976. Forest overstory vegetation and environment on the Missouri River floodplain in North Dakota. Ecological Monographs 46:59-84.

Mahoney, J.M., and S.B. Rood. 1998. Streamflow requirements for cottonwood seedling recruitmentan integrative model. Wetlands 18:634-645.

MCBRide, J.R., and J. Strahan. 1984. Establishment and survival of woody riparian species on gravel bars of an intermittent stream. American Midland Naturalist 112:235-245.

MerritT, D.M., AND D.J. CoOper. 2000. Riparian vegetation and channel change in response to river regulation: a comparative study of regulated and unregulated streams in the Green River Basin, USA. Regulated Rivers: Research \& Management 16:543-564.

Merritt, D.M., AND N.L. Poff. 2010. Shifting dominance of riparian Populus and Tamarix along gradients of flow alteration in western North American rivers. Ecological Applications 20:135-152.

PofF, N.L., J.D. Allan, M.B. Bain, J.R. Karr, K.L. Prestegaard, B.D. Richter, R.E. Sparks, and J.C.
Stromberg. 1997. The natural flow regime: a paradigm for river conservation and restoration. BioScience 47:769-784.

Polzin, M.L., AND S.B. Rood. 2006. Effective disturbance: seedling safe sites and patch recruitment of riparian cottonwoods after a major flood of a mountain river. Wetlands 26:965-980.

R Development Core Team. 2011. R: a language and environment for statistical computing. R Foundation for Statistical Computing, Vienna, Austria; [cited 8 June 2011]. Available from: http://www.R-project.org/.

Rood, S.B., C. Hillman, T. Sanche, and J.M. Mahoney. 1994. Clonal reproduction of riparian cottonwoods in southern Alberta. Canadian Journal of Botany 72:1766-1774.

Rood, S.B., AND J.M. MAHONEY. 1990. Collapse of riparian poplar forests downstream from dams in western prairies: probable causes and prospects for mitigation. Environmental Management 14:451-464.

Scott, M.L., G.T. Auble, and J.M. Friedman. 1997. Flood dependency of cottonwood establishment along the Missouri River, Montana, USA. Ecological Applications 7:677-690.

Shafroth, P.B., J.C. Stromberg, and D.T. Patten. 2002. Riparian vegetation response to altered disturbance and stress regimes. Ecological Applications 12: $107-123$.

Stokes, M.A., And T.L. SmiLey. 1968. An introduction to tree-ring dating. University of Chicago Press, Chicago, IL. 73 pp.

StromberG, J.C. 1997. Growth and survivorship of Fremont cottonwood, Goodding willow, and salt cedar seedlings after large floods in central Arizona. Great Basin Naturalist 57:198-208.

USDA Forest Service. 1990. Silvics of North America. Volume 2, Hardwoods. Agricultural Handbook 654, United States Department of Agriculture, Washington, DC.

Received 17 July 2012

Accepted 16 November 2012 